NOTE

\title{
Reproductive aspects of the flag cichlid Mesonauta insignis in várzea lakes of the Central Brazilian Amazon
}

\author{
Tânia Cristiane Gonçalves da Silva ${ }^{1, *}$, Daíza Lima ${ }^{1}$, Ana Carolina Prado-Valladares ${ }^{1}$, \\ Maria Auxiliadora Pantoja Ferreira², Rossineide Martins da Rocha², \\ Helder Lima de Queiroz ${ }^{1}$
}

${ }^{1}$ Mamirauá Institute for Sustainable Development, MISD, 69470-000 Amazonas, Brazil

${ }^{2}$ Federal University of Pará, (UFPA), 66075-110 Pará, Brazil

\begin{abstract}
We describe the most important reproductive aspects of the flag cichlid Mesonauta insignis in the floodplain (várzea) lakes of the Central Brazilian Amazon. Between September 2005 and August 2006, fish were collected monthly from mattresses of aquatic macrophytes. Biometric measurements as well as macroscopic and microscopic analyses of the gonads were performed. Standard body lengths ranged from 2.4 to $9.3 \mathrm{~cm}$, and weight-length relationships were indicative of isometric growth patterns. Reproduction events were detected in all months, but the gonadosomatic index indicated a reproductive season from October to February (during low and rising water periods), reaching a reproductive peak in February. Average fecundity was $1184 \pm$ 40.82 (mean \pm SD) mature oocytes. $M$. insignis exhibits an asynchronous oocytal development, characteristic of multiple spawnings. Morphological and histological analyses indicated 5 gonadal maturation stages for females. Average standard length at first sexual maturation was $5.18 \mathrm{~cm}$ for females and $5.5 \mathrm{~cm}$ for males. M. insignis shows late sexual maturation. Taken together, these aspects suggest that a life history strategy of 'equilibrium' predominates in the species; consequently, $M$. insignis can be considered vulnerable to high extraction rates, and can only be exploited sustainably if adequate precautionary management procedures are adopted. Some management measures are suggested for the exploitation of this species in the Central Amazon.
\end{abstract}

KEY WORDS: Fecundity - Gonad histology - Management $\cdot$ Life history strategies $\cdot$ Sexual maturation $\cdot$ Spawning

\section{INTRODUCTION}

The flag cichlid Mesonauta insignis is widespread in the Amazon River and the upper Negro River basins in Brazil, and in the Orinoco River basin in Colombia and Venezuela (Kullander 2003). This species is benthopelagic, omnivorous, lays its eggs on submerged leaves near the surface and shows long and intense bi-parental care (Keith et al. 2000), a widespread behavior among members of this family (Keenleyside 1991, Turner et al. 2001).

\footnotetext{
*Corresponding author: tania@mamiraua.org.br
}

$M$. insignis is one of the most dominant species in the water bodies of the middle Solimões River floodplain (i.e. várzea lakes) (Hercos et al. 2013), and is also important in the aquarist industry. Although it is not listed among those fishes frequently exported (Prang 2007, Anjos et al. 2009), it is very similar in appearance to Mesonauta festivus, and can be easily misidentified by those involved in the exportation of ornamental fish. M. insignis was recently included in the official list of Brazilian species that are permitted to be exploited for ornamental purposes

(C) The authors 2015. Open Access under Creative Commons by Attribution Licence. Use, distribution and reproduction are unrestricted. Authors and original publication must be credited. 
(MPA-MMA 2012). In spite of its ecological and economic importance, the biology of this cichlid remains largely unknown, which makes it difficult to sustainably exploit its natural population. Studies on the reproductive biology of Amazonian ornamental fish species in their natural environments are relatively rare (Tlusty 2002).

There have been no published studies on the reproduction of $M$. insignis inhabiting the várzea environment. The results of such an investigation could aid in the sustainable use of the species and contribute to its management in this region. Therefore, this work was aimed at characterizing the main reproductive aspects of $M$. insignis in the várzea environment of the Central Amazon, and to provide some of the biological bases for its sustainable use.

\section{MATERIALS AND METHODS}

This study was conducted in 5 lakes in the floodplains of the Central Brazilian Amazon, an extension of lowlands annually flooded by white waters (sediment, nutritient-rich waters originating from the foothills of the Andes) (Neill et al. 2006). These floodplain lakes, Tracajá, Juruá Grande, Juruazinho, Araçazinho and Pagão (Fig. 1), belong to Mamirauá Sustainable Development Reserve (MSDR), a protected area limited by the Japurá and Solimões Rivers and the Auati-Paraná channel in Amazonas State, Brazil. MSDR encompasses 1124000 hectares (Queiroz \& Peralta 2006), and is strongly influenced by the flood

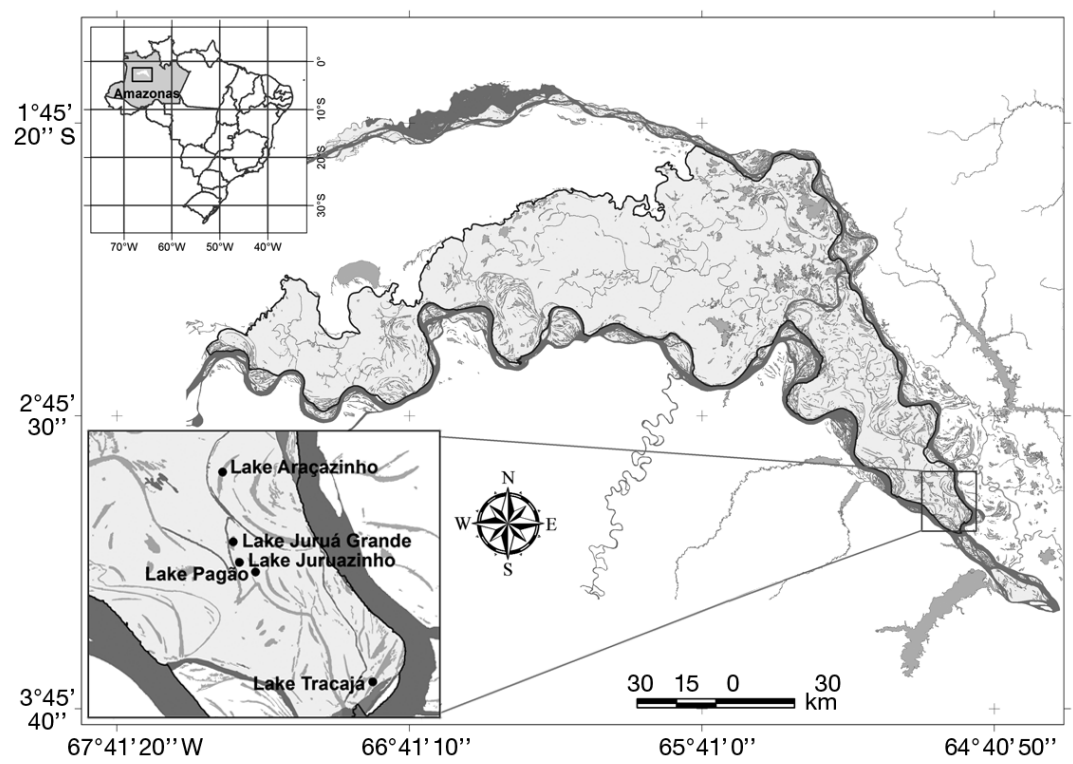

Fig. 1. Mamirauá Reserve and the lakes where Mesonauta insignis were collected pulse (Junk et al. 1989), a periodic oscillation of the water level that defines hydrological periods and contributes to all major phenological processes in this ecosystem. These hydrological periods or phases are hereafter referred to as 'low water', 'rising water', 'high water' and 'dropping water' (Ramalho et al. 2009).

Fish were collected monthly during a complete hydrological cycle from September 2005 to August 2006. Every month, fish were sampled at 5 randomly chosen points of aquatic vegetation in each lake. Sampling occurred in $4 \times 4 \mathrm{~m}$ blocks of aquatic macrophytes encircled by multifilament seine nets $(0.3 \mathrm{~cm}$ mesh size, $6 \mathrm{~m}$ wide, $30 \mathrm{~m}$ long). All specimens of Mesonauta insignis present in these blocks were removed from the seine nets and transported to a field laboratory. Fish were fixed in $10 \%$ formalin solution for $24 \mathrm{~h}$, then transported to the laboratory in the nearby town, washed with running water and stored in $70 \%$ alcohol solution.

All fish were measured for total and standard length $(\mathrm{SL} ; \mathrm{mm})$ and weighed $(\mathrm{g})$. Sex and gonadal maturation stages were visually determined and classified as 'immature', 'maturing', 'mature', 'spawned' (for females) and 'resting', based on an adapted system of maturation stages (Núñez \& Duponchelle 2009). After the macroscopic analysis, samples from 150 ovaries were removed and submitted to routine histological processing for embedding in paraffin (Prophet et al. 1995) as follows: dehydrated with increasing solutions of ethyl alcohol (70 to $100 \%$ ), diafanized in xylol and placed in paraffin to allow cuts of $5 \mu \mathrm{m}$ thick slices. Standard hematoxylin and eosin (H\&E) staining was performed, and a total of 100 slides were prepared, analyzed and photographed under a microscope (Axiostar Plus 1169-151, Carl Zeiss).

The reproductive period was determined using the gonadosomatic index (GSI). GSI is a quantitative indication of the reproductive period. The variation in GSI for females (Vazzoler 1996) was defined as:

$$
\mathrm{GSI}=\left(W_{\mathrm{o}} / W_{\mathrm{t}}\right) \times 100
$$

where $W_{\mathrm{o}}$ and $W_{\mathrm{t}}$ are the weight of the ovary and total body weight, respectively.

ANOVA and post-hoc Tukey's tests were performed to detect differences in $\Delta$ GSI among months of the hydrological cycle. Fecundity was determined by the gravimetric method (Vazzoler 1996). 
Oocytal development was determined based on the frequency distribution of oocyte diameters, and the number of classes found (diameters were measured using digital calipers and a stereomicroscope) in 5 mature ovaries. Modal groups were interpreted in diagrams (Vazzoler 1996). Spawning strategy was determined by analysis of oocyte development pattern and by histology (Núñez \& Duponchelle 2009).

The average size at first sexual maturation was determined from the frequency of mature fish in specific length classes. These were depicted in a graph and adjusted to a logistic equation:

$$
F=\frac{1}{1+\exp \left[-R\left(\mathrm{SLC}-L_{50}\right)\right]}
$$

where $F$ is the ratio of mature fish in each length class; $R$ is the rate of change from the non-reproductive to reproductive state; SLC is the mid-value of the length class and $L_{50}$ is the size at first maturation when $50 \%$ of the adult fish are sexually mature (King 1995).

The precocity in reproductive development was calculated as the relationship between $L_{50}$ and asymptotic length $\left(L_{\infty}\right)$, obtained from the maximum length in the sample (Pauly 1984). Therefore, reproductive precocity of $M$. insignis was calculated by the formula:

$$
D=\frac{L_{50}}{L_{\infty}}
$$

All statistical tests were performed with BioEstat 5.0 (Ayres et al. 2007).

\section{RESULTS AND DISCUSSION}

In total, 380 individual Mesonauta insignis were collected and used in the analysis of reproductive biology. Microscopic analysis of the ovaries confirmed 5 developmental stages (immature, maturing, mature, spawned and resting) (Fig. 2), corroborating the stages identified macroscopically. Immature ovaries exhibited oogonias and numerous oocytes in stages I (previtellogenic) and II (early vitellogenesis). The maturing ovaries contained large amounts of oocytes in stages I, II and III (vitellogenic); mature ovaries had a small amount of oocytes in stages I, II, III and many oocytes in stage IV (vitellogenic). These cells presented acidophilic cytoplasm and full yolk granules. In the spawned ovaries, the parenchyma was characterized by the presence of postovulatory follicles and atresic oocytes, and by a small amount of oocytes in stages I and II. In the resting ovaries, numerous stage I and II oocytes were found, sur- rounded by a fibrillar network. This indicates an asynchronous pattern of gonadal development, characteristic of multiple spawners (as evidenced by the presence of oocytes in stages I and II and postovulatory follicles, indicating the removal of mature oocytes). The stages of gonadal development of $M$. insignis exhibited similar characteristics to those observed in other cichlids, such as Cichla pleiozona, and other Amazonian species, such as Plagioscion squamosissimus (Núñez \& Duponchelle 2009).

The frequency distribution of oocyte diameters was also indicative of multiple spawnings. The graphs indicate a distribution in 2 modes, and a synchronic development of oocytes in 2 groups (Fig. 3), confirming the histological analyses. Microscopic analysis revealed that these 2 modes occur in one reproductive season. This result is similar to that obtained by Favero et al. (2010a) for the same species living in black waters (nutrient-poor waters originating in terrains of the Guianean or Central Brazil shields) at the igarapés of Amanã, which was also determined to be a multiple spawner.

A seasonal trend was observed in $M$. insignis reproduction, suggesting a period of high reproductive activity, or a reproductive season, starting during the low water phase (October) and lasting until the first part of the rising water phase (March), reaching a peak in the early months of the rising water phase (GSI $=4.7$ ) in February. Variation in GSI during this period was significantly higher than during the nonreproductive season $(F=4.382 ; \mathrm{p}=0.002)$.

Reproductive activity of most Amazonian species intensifies as environmental conditions favor their recruitment (Lowe-McConnell 1999, Barletta et al. 2010). This starts when food abundance is higher, and autochthonous prey are concentrated in water bodies during the low water phase. In the present study, at the end of the low water phase, $M$. insignis showed intense feeding and ripe gonads. Rising water provides the ideal nutritional conditions for most Amazonian fish species, and thus favorable conditions for the conclusion of sexual maturation, gametogenesis and spawning (Vazzoler 1996), perhaps explaining the close relationship between water levels and GSIs reported for a large number of Amazonian fish species (Barthem \& Fabré 2003)

Average fecundity recorded for $M$. insignis was $1184 \pm 40.82$ (mean \pm SD) vitellogenic oocytes (>0.6 mm diameter), ranging from 840 to 1840 oocytes female $^{-1}$. Favero et al. (2010a), investigating this species at a different site, reported lower fecundity: an average of $609 \pm 178.3$ oocytes female ${ }^{-1}$, ranging from 386 to 920 mature oocytes female ${ }^{-1}$. Species that ex- 

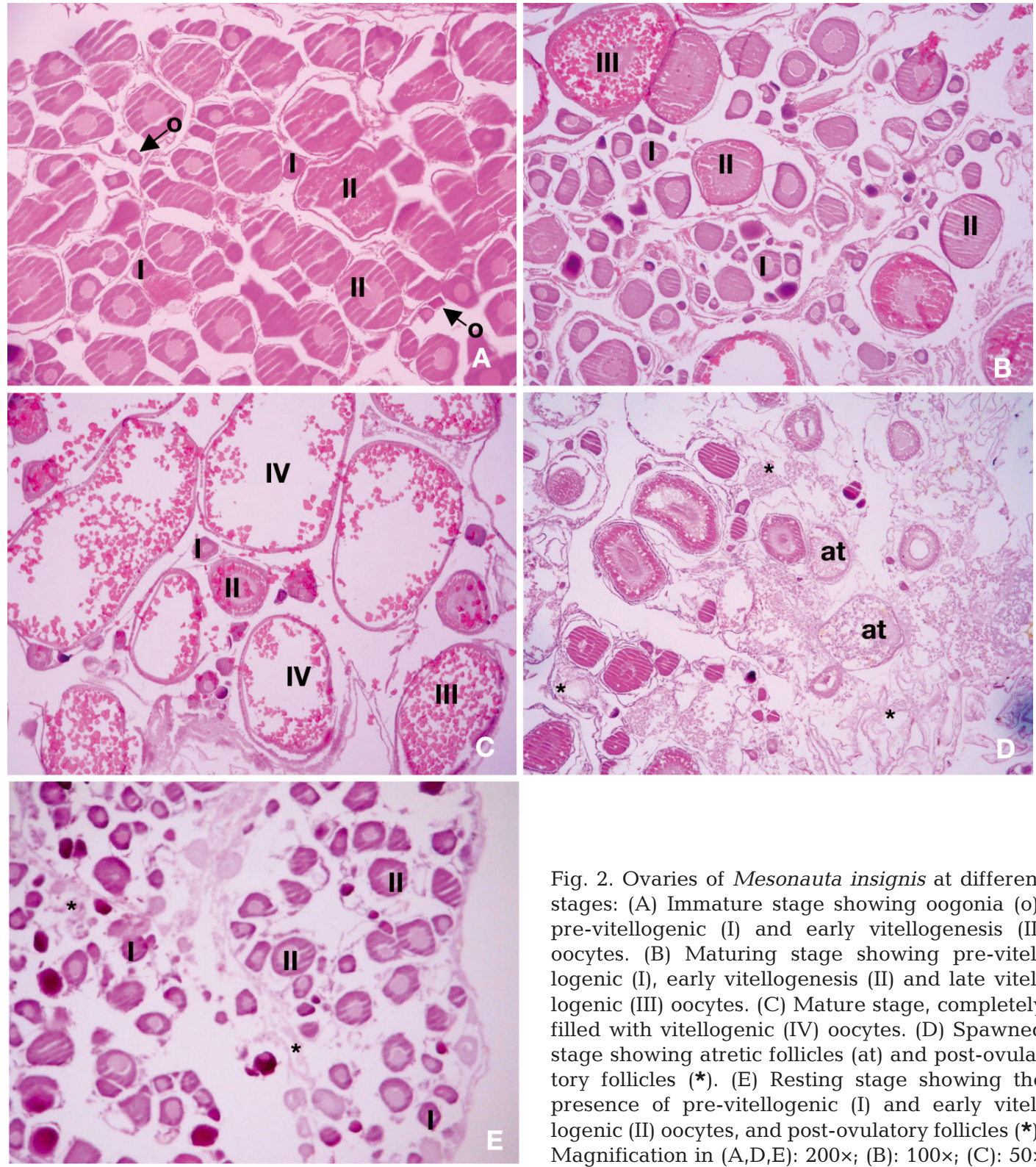

Fig. 2. Ovaries of Mesonauta insignis at different stages: (A) Immature stage showing oogonia (o), pre-vitellogenic (I) and early vitellogenesis (II) oocytes. (B) Maturing stage showing pre-vitellogenic (I), early vitellogenesis (II) and late vitellogenic (III) oocytes. (C) Mature stage, completely filled with vitellogenic (IV) oocytes. (D) Spawned stage showing atretic follicles (at) and post-ovulatory follicles $(*)$. (E) Resting stage showing the presence of pre-vitellogenic (I) and early vitellogenic (II) oocytes, and post-ovulatory follicles (*). Magnification in (A,D,E): 200x; (B): 100 $x_{i}(C)$ : $50 \times$

hibit parental care usually show lower fecundity compared to species that do not (Sato et al. 2003). Some neotropical members of the Cichlidae family that are similar in size to Mesonauta show similar or higher fecundity, such as Heros efasciatus, with 2502 oocytes female $^{-1}$ (Favero et al. 2010b), or Acarichthys heckelli, with 1341 oocytes female $^{-1}$ (Favero et al. 2010a).

In our study site, $M$. insignis females reached sexual maturation at $5.18 \mathrm{~cm} \mathrm{SL}$ and males at $5.5 \mathrm{~cm} \mathrm{SL}$ (Fig. 4). The average length at first sexual maturation is related to the growth pattern of each species, and inter-specific variations in space and time can have an important influence on the population (LoweMcConnell 1999). The same species, living in black water environments, averaged $6.41 \mathrm{~cm} \mathrm{SL}$ at first reproduction (Favero et al. 2010a), which is significantly higher than in MSDR. This suggests that when living in richer environments, $M$. insignis grows faster and individuals mature earlier. Most fish species exhibit a decrease in size at first sexual maturation (along with a reduction in other growth patterns) as a result of changes in population densities. Whitewater bodies, such as várzea lakes, harbor many species of aquatic predators that might add new sources of mortality (Henderson \& Crampton 1997). The increase in mortality rates may cause a reduction in size at first sexual maturation as a compensatory response (Rose et al. 2001). 


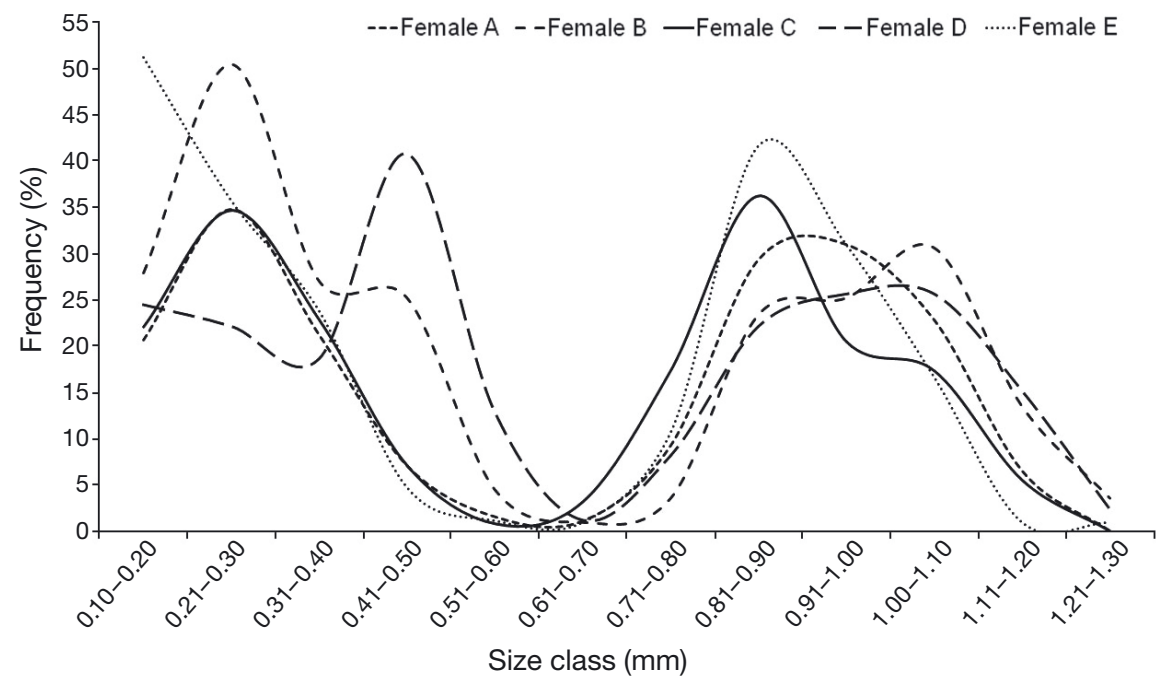

Fig. 3. Frequency distribution of oocyte diameters (mm) for 5 mature Mesonauta insignis females from the study site

The relationship between $L_{50}$ and $L_{\infty}$ (representing the precocity of sexual development) differed between males (0.54) and females (0.67); however, these rates suggest late sexual maturation for M. insignis (Vazzoler 1996). Late maturation might improve overall reproductive success, with higher fry survival resulting from additional parental investment, such as production of larger oocytes, longer autotrophic periods, and more efficient parental care (Zeug \& Winemiller 2007). During field work, we observed pairs of $M$. insignis in the wild performing bi-parental care, actively guarding their offspring.

Cichlid species are usually considered equilibrium strategists (Winemiller 1989). However, at our study

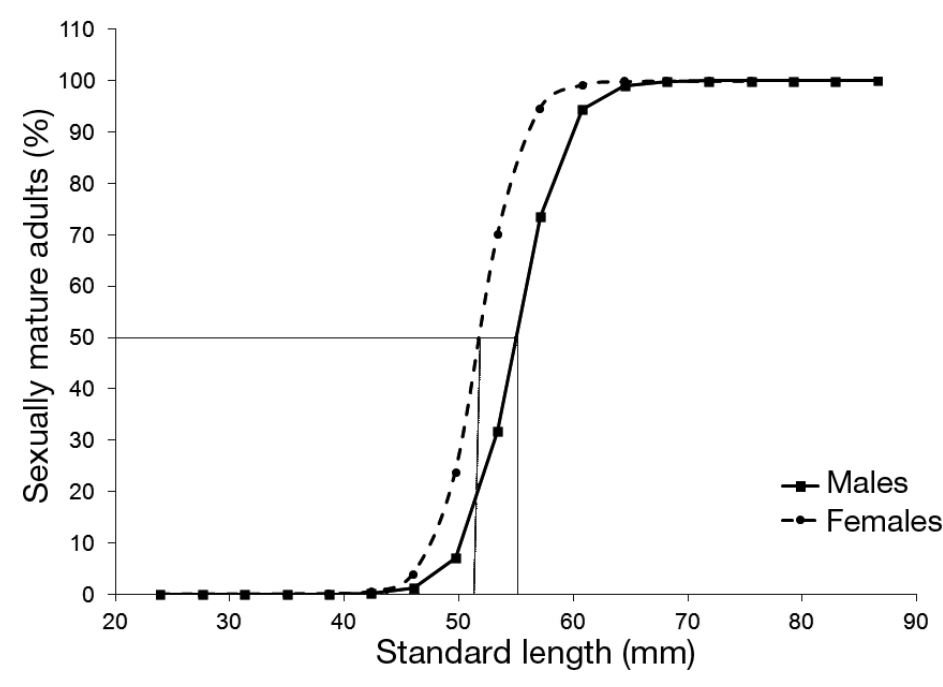

Fig. 4. Average size at first sexual maturation $\left(L_{50}\right)$ for Mesonauta insignis females and males site, while some reproductive aspects of $M$. insignis appeared to confirm this life history strategy (such as late sexual maturation, low fecundity, high survival rates and multiple spawning), others more closely resembled a seasonal or opportunistic strategy, such as small size and a seasonal peak of reproductive activity. Thus, some Amazonian cichlid species, such as $M$. insignis, probably show a more intermediate life history strategy (i.e. an equilibrium-opportunistic strategy; Winemiller \& Rose 1992).

Increased knowledge of the reproductive biology of this species is fundamental for the establishment of management criteria to regulate its exploitation. Minimal size at capture, regulation of the maximum amount of specimens caught, and closed seasons are all potential measures to ensure sustainable exploitation (Hilborn \& Walters 1992). Based on the results presented here, we suggest that $5.3 \mathrm{~cm}$ SL be adopted as the minimal size for capture in this area, and to avoid captures during the reproductive period (January to March). Given the predominance of an equilibrium life strategy, it is clear that $M$ insignis can only be sustainably exploited if adequate precautionary management measures are taken.

Acknowledgements. The authors acknowledge the support from the Mamirauá Sustainable Development Institute MSDI (IDSM), the Federal University of Pará (UFPA), and the PostGraduate Program in Animal Science PGPAS (PPGCAN). We also thank CNPq and CAPES for the support conceded. Thanks to Ruiter da Silva, and to Jonas Oliveira, for their support during this study. IBAMA provided permits for fish collection, under license number 15/2006 NRP, file 02005.002120/06-31. We also thank 4 anonymous reviewers for their valuable suggestions on the manuscript.

\section{LITERATURE CITED}

Anjos HDB, Amorim RMS, Siqueira JA, Anjos CR (2009) Exportação de peixes ornamentais do estado do Amazonas, Bacia Amazônica, Brasil. Boletim Inst Pesca 35: $259-274$

Ayres M, Ayres M Jr, Ayres DL, Santos AAS (2007) BioEstat 5.0: aplicações estatísticas nas áreas das ciências biológicas e médicas. Instituto de Desenvolvimento Sustentável Mamirauá, Belém

Barletta M, Jaureguizar AJ, Baigun C, Fontoura NF and others (2010) Fish and aquatic habitat conservation in South America: a continental overview with emphasis on 
Neotropical systems. J Fish Biol 76:2118-2176

Barthem RB, Fabré NN (2003) Biologia e diversidade dos recursos pesqueiros da Amazônia. In: Ruffino ML (ed) A pesca e os recursos pesqueiros na Amazônia Brasileira. IBAMA/ProVárzea, Manaus, p 17-62

Favero JM, Pompeu PS, Prado-Valladares AC (2010a) Aspectos reprodutivos de duas espécies de ciclídeos na Reserva de Desenvolvimento Sustentável Amanã, Amazonas, Brasil. Rev Bras Zoocienc 12:117-124

Favero JM, Pompeu PS, Prado-Valladares AC (2010b) Biologia reprodutiva de Heros efasciatus Heckel, 1840 (Pices, Cichlidae) na Reserva de Desenvolvimento Sustentável Amanã-AM, visando seu manejo sustentável. Acta Amazon 40:373-380

Henderson PA, Crampton WGR (1997) A comparison of fish diversity and abundance between nutrient-rich and nutrient-poor lakes in the Upper Amazon. J Trop Ecol 13: 175-198

Hercos AP, Sobansky M, Queiroz HL, Magurran AE (2013) Local and regional rarity in a diverse tropical fish assemblage. Proc R Soc B 280:20122076

Hilborn R, Walters CJ (eds) (1992) Quantitative fisheries stock assessment: choice, dynamics \& uncertainty. Chapman \& Hall, New York, NY

Junk WJ, Bayley PB, Sparks RE (1989) The flood pulse concept in river-floodplain systems. Publ Spec Can Sci Halieut Aquat 106:110-127

Keenleyside MHA (ed) (1991) Cichlid fishes: behaviour, ecology and evolution. Chapman \& Hall, London

Keith P, Le Bail PY, Planquette P (2000) Atlas des poissons d'eau douce de Guyane. Institut d'Ecologie et de Gestion de La Biodiversité, Museum national D'Histoire Naturelle, Paris

King M (1995) Fisheries biology, assessment and management. Fishing News Books, Oxford

Kullander SO (2003) Family Cichlidae. In: Reis RE, Kullander $\mathrm{SO}$, Ferraris CJ Jr (eds) Check list of freshwater fishes of South and Central America. Edipucs, Porto Alegre, p 605-655

Lowe-McConnell RH (1999) Estudos ecológicos de comunidades de peixes tropicais. EDUSP, São Paulo

MPA-MMA (Ministério da Pesca e Aquicultura - Ministério do Meio Ambiente) (2012) Instrução Normativa Interministerial No. 001, de 3 Janeiro de 2012. www.icmbio.gov. br/cepsul/images/stories/legislacao/Instrucao_normativa/ 2012/in_inter_mpa_mma_01_2012_exploracaopeixesna tivosexoticosaguascontinentais.pdf

Neill C, Elsenbeer H, Krusche AV, Lehmann J, Markewitz D, Figueiredo RO (2006) Hydrological and biogechemical processes in a changing Amazon: results from small watershed studies and the large-scale biosphereatmosphere experiment. Hydrol Process 20:2467-2477

Editorial responsibility: Roderick Finn,

Bergen, Norway
Núñez J, Duponchelle F (2009) Towards a universal scale to assess sexual maturation and related life history traits in oviparous teleost fishes. Fish Physiol Biochem 35: $167-180$

Pauly D (1984) Fish population dynamics in tropical waters: a manual for use with programmable calculators. International Center for Living Aquatic Resources Management, Manila

Prang G (2007) An industry analysis of the freshwater ornamental fishery with particular reference to the supply of Brazilian freshwater ornamentals to the UK market. Uakari 3:7-51

Prophet EB, Milis B, Arrington JB, Sobin LH (1995) Métodos histotecnológicos. Instituto de Patologia de las Fuerzas Armadas de los Estados Unidos de America (AFIP), Washington, DC

Queiroz HL, Peralta N (2006) Reserva de desenvolvimento sustentável: manejo integrado dos recursos naturais e gestão participativa. In: Garay I, Becker BK (eds) Dimensões humanas da biodiversidade. Vozes, Petrópolis, p 447-483

Ramalho EE, Macedo J, Vieira TM, Valsecchi J, Calvimontes J, Marmontel M, Queiroz HL (2009) Ciclo hidrológico nos ambientes de várzea da Reserva de Desenvolvimento Sustentável Mamirauá - Médio Rio Solimões, período de 1990 a 2008. Uakari 5:61-87

> Rose KA, Cowan JH Jr, Winemiller KO, Myers RA, Hlborn R (2001) Compensatory density dependence in fish populations: importance, controversy, understanding and prognosis. Fish Fish 2:293-327

Sato Y Fenerich-Verani N, Nuñer APO, Godinho HP, Verani JR (2003) Padrões reprodutivos de peixes da bacia do São Francisco. In: Godinho HP, Godinho AL (eds) Águas, peixes e pescadores do São Francisco das Minas Gerais. PUC Minas Gerais, Belo Horizonte, p 229-274

Tlusty M (2002) The benefits and risks of aquacultural production for the aquarium trade. Aquaculture 205: 203-219

Turner GF, Seehausen O, Knight ME, Allender CJ, Robinson RL (2001) How many species of cichlid fishes are there in African lakes? Mol Ecol 10:793-806

Vazzoler AEAM (1996) Biologia da reprodução de peixes teleósteos: teoria e prática. EDUEM, Maringá

Winemiller KO (1989) Patterns of variation in life history among South American fishes in seasonal environments. Oecologia 81:225-241

Winemiller KO, Rose KA (1992) Patterns of life-history diversification in North American fishes: implications for population regulation. Can J Fish Aquat Sci 49:2196-2218

Zeug SC, Winemiller KO (2007) Ecological correlates of fish reproductive activity in floodplain rivers: a life-historybased approach. Can J Fish Aquat Sci 64:1291-1301

Submitted: April 11, 2014; Accepted: March 19, 2015

Proofs received from author(s): May 15, 2015 